\begin{tabular}{l|l|l|l|l}
\hline Volume 1 & Issue 1 & February (2021) & DOI: 10.47540/ijias.v1i1.157 & Page: $52-58$ \\
\hline
\end{tabular}

\title{
Bureaucracy Involvement in Local Election In Konawe Selatan District
}

\author{
M. Najib Husain ${ }^{1}$, Muh. Nasir ${ }^{2}$, Suryani B.B ${ }^{3}$ \\ ${ }^{1}$ Department of Communication Science, Universitas Halu Oleo, Indonesia \\ ${ }^{2}$ Department of Political Science, Universitas Halu Oleo, Indonesia \\ ${ }^{3}$ Department of Public Administration, Universitas Halu Oleo, Indonesia
}

Corresponding Author: M. Najib Husain; Email: muh.najib.husain@gmail.com

\begin{tabular}{ll}
\hline A R T I C L E I N F O & A B S T R A C T \\
$\begin{array}{l}\text { Keywords: Bureaucracy, Local } \\
\text { Election, Konawe Selatan District. }\end{array}$ & $\begin{array}{l}\text { Local Election often makes the bureaucratic apparatus face a dilemma, between } \\
\text { being neutral or being involved in politics. Ideally and based on the rules of law, } \\
\text { bureaucracy is required to behave professionally and neutral from politics. Despite } \\
\text { that in reality it is difficult for the bureaucratic apparatus to be neutral, moreover }\end{array}$ \\
$\begin{array}{l}\text { Received }: 28 \text { December } 2020 \\
\text { Revised }: 21 \text { January } 2021\end{array} \quad \begin{array}{l}\text { when they are faced with the temptations and pressures of power. This article } \\
\text { hecepted }: 08 \text { February } 2021\end{array}$ & $\begin{array}{l}\text { District, by outlining the modes of bureaucratic involvement and identifying factors } \\
\text { of bureaucratic involvement. This study found that the bureaucrats involved in the } \\
\text { Local Election were state civil servants and village government officials. Factors } \\
\text { that encourage bureaucratic involvement are: the status of incumbent regional head } \\
\text { candidates who remain active during the implementation of the elections, the lure of } \\
\text { promotion for the bureaucratic apparatus, weak sanctions by the State civil } \\
\text { apparatus commission and regional head candidates, and weak supervision and } \\
\text { enforcement of election supervisory agencies (Bawaslu and ranks). }\end{array}$ \\
\hline
\end{tabular}

\section{INTRODUCTION}

The truth is, the bureaucracy is required to be neutral, and become a mediator between the interests of society and the state. This understanding develops from the ideal type of Webber bureaucracy, where the bureaucracy is filled by personally free individuals (Thoha, 2009). However, in reality, bureaucracy is difficult to be free. In the momentum of the Local Election, the bureaucratic apparatus often faces a dilemma, to have a neutral attitude or is involved in politics. Both of these options do not provide certainty for the bureaucratic apparatus, being neutral or not neutral, and the consequences can have bad implications, or otherwise make the individual bureaucrats become decent (career-wise).

In contrast to that, institutionally, the involvement of the bureaucracy in politics has certainly had bad implications for the continuity of democracy. The hierarchical and solid nature of the bureaucracy will be very effective if it is used as an instrument of power. Moreover, the bureaucracy has monopoly power in terms of expertise and information that can free them from political control and protect the scope of bureaucratic assignments. With this capacity, the bureaucracy can act as a tool for expanding the domination of state power and state repression.

In this condition, democracy will putrefaction. The portrait of bureaucracy as an instrument of power is a common phenomenon in Indonesia. In the Old Order era, the composition of the bureaucracy was filled by political partisans (Rozi, 2006). In the New Order era, the involvement of bureaucracy in politics was very strong. Bureaucracy, military, and Golkar were used by Soeharto as instruments to maintain power (Suryadinata, 1992). The fall of Soeharto did not necessarily break the close relationship between bureaucracy and politics. On the contrary, the 
relationship between bureaucracy and politics has only changed places, from previously controlled centrally, now spreading in local government units, along with granting decentralization to the regions.

The implications of this decentralization have given rise to many Little Soeharto's at the local level, where in practice the power is completely and partially reproduced, the new order's ways of seizing and maintaining power, one of which is politicizing the bureaucracy. Several studies on the involvement of the bureaucracy in the local political arena have become interesting findings in reading Indonesian politics at the sub national level in Banten, bureaucratic politicization is used by incumbents as an instrument to win the Local Election (Hamid, 2011). A similar phenomenon is also found in Takalar District and Jambi Province. Between bureaucracy and politics, a kind of patronage interrelationship is built, where politicians (incumbents) use the bureaucracy to win the Pilkada, and bureaucrats provide support to get a position (Agustino, 2014). 2013).

The phenomenon of bureaucratic involvement is also found in Konawe Selatan District. The involvement of the bureaucracy in the momentum of the Local Election is a recurring incident. Referring to the Bawaslu report, violations of bureaucratic involvement rank first, from various types of violations in the simultaneous Local Election held in 2020. Then this article aims to describe the model of bureaucratic involvement and identify the bureaucratic neutrality factors in the Konawe Selatan District.

\section{METHODS}

This study used a qualitative descriptive method (Creswell, 2014). Data collection techniques were carried out through library research. Literature study is carried out by tracing written sources from various sources: books, journals, Bawaslu reports, and mass media reports related to the involvement of the bureaucracy in the Pilkada. Furthermore, qualitative data analysis was carried out (Miles and Huberman, 2005). The series of data analysis activities began with organizing data, sorting through it, looking for and finding patterns, presenting data, and drawing conclusions.

\section{RESULTS AND DISCUSSION}

In general, based on the findings and reports of Bawaslu, the types of Local Election violations in Konawe Selatan District consist of nine forms, namely involvement of the State civil apparatus (ASN), violations involving election administrators, the involvement of village heads and their apparatus, campaign advertisements in the mass media, money politics, use of public facilities, the politicization of religious groups, races and groups (SARA), campaign outside the schedule and election law-breaking. Of the nine types of violations, ASN involvement ranked first, were of the 244 findings and reports, $58 \%$ or 142 cases involved ASN involvement. Furthermore, consecutively, violations involving election organizers (24\%), involvement of village heads, village officials, and village local assistants $(9 \%)$, off-schedule campaigns (3\%), money politics $(3 \%)$, use of public facilities (1\%), election crimes $(1 \%)$, campaign advertising in the media (1\%) and politicization of SARA $(0.01 \%)$.

Picture 1. Election 2018 Violation Classification in Konawe Selatan District

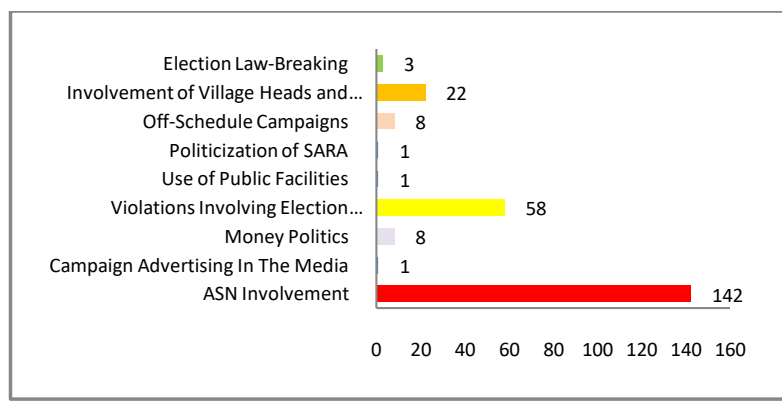

Source: Bawaslu Sultra (reprocessed) 2020.

As the table above shows that the involvement of the bureaucracy in the Pilkada is the type of violation that most often occurs in Konawe Selatan District. If classified in more detail, the bureaucracy involved consists of: State civil servants/Civil Servants (ASN/PNS) and village government officials (Village Heads, Village Officials, and Village Local Assistants). The involvement of the two levels of bureaucracy, if added together, 
contributed to $67.21 \%$ of the types of violations in the Local Election in Konawe Selatan District. This indicates that the bureaucratic apparatus in Konawe Selatan District is very actively involved in the politics of regional head elections.

Picture 2. Number of Cases According to Bureaucratic Classification.

\begin{tabular}{ll|} 
& ASN \\
& \\
& Village \\
Heads, Village \\
Officials and Village \\
Local Assistants
\end{tabular}

Source: Bawaslu Sultra (reprocessed), 2020.

ASN necessities to maintain neutrality (not getting involved in politics) have been contained in various laws and regulations, including Constitution Number 5 of 2014 concerning State Civil Service, Government Regulation Number 42 of 2004 concerning Corps Soul Development and Civil Servant Code of Ethics, Circular Minister of Administrative Reform and Bureaucratic Reform (MenPAN-RB) RI Number: B/71/M.SM.00.00/ 2017 regarding the Implementation of Neutrality for ASN at the 2018 Concurrent Election, 2019 Legislative General Election, and Presidential and Vice General Election President of 2019, as well as Government Regulation Number 53 of 2010 concerning Civil Servant Discipline.

Constitution Number 5 of 2014 concerning State Civil Servants, explains that in carrying out their duties and responsibilities as ASN, one of the principles that must be upheld by the State Civil Apparatus is to uphold the principle or belief of neutrality. Article 2 letter $f$ of Constitution Number 5 Year 2014 concerning State Civil Servants explains that what is meant by the Principle of Neutrality is that every ASN employee does not take sides with any form of influence, and does not take sides with the interests of anyone. Deviation from the neutrality principle by the State civil apparatus is a form of ethical and disciplinary violations. Furthermore, Article 3 Letter b of the ASN Constitution states that ASN as a profession is based on the principles of the Code of Ethics and code of conduct. Furthermore, Article 5 paragraph (2) letter 1 states that the ASN code of ethics and code of conduct contains behavior regulation, so that ASN employees implement the provisions of laws and regulations regarding ASN Employee Discipline.

The necessities for civil servants (PNS) in maintaining ethics are contained in Government Regulation Number 42 of 2004 concerning Corps Spirit Development and Civil Servant Code of Ethics, Article 11 letter c, that in terms of ethics towards themselves, PNS are required to avoid conflicts of personal interest. group or group. The necessities that explain in more detail about the ethics of civil servants are contained in the Circular of the Minister of Administrative Reform and Bureaucratic Reform (MenPAN-RB) RI Number: B /71/M.SM.00.00/2017 dated 27 December 2017 regarding the Implementation of Neutrality for ASN at Election Implementation Simultaneously in 2018, the 2019 Legislative General Election, and the 2019 Presidential and Vice-Presidential Election. Through this circular, the points prohibited for civil servants from committing actions that indicate involvement in practical politics/affiliation with political parties include:

1. PNS are prohibited from making approaches to political parties related to their proposed plans or other people as candidates for regional head/deputy regional head;

2. PNS are prohibited from placing banners/ billboards promoting themselves or others as candidates for Regional Head/Deputy Regional Head;

3. Civil servants are prohibited from declaring themselves as candidates for Regional Head/ Deputy Regional Head.;

4. Civil servants are prohibited from attending the declaration of the candidate pair/candidate pair for regional head/deputy regional head with or without using the attributes of the candidate pair/political party attributes;

5. PNS are prohibited from uploading, responding (such as likes, comments, and the similar), or 
spreading pictures/photos of the regional head candidate/candidate pair, vision, and mission of the regional head candidate pair/candidate pair through online media and social media;

6. PNS are prohibited from taking photos together with the prospective regional head/deputy regional head candidates by following the hand symbol/gesture used as a form of partiality;

7. PNS are prohibited from becoming speakers/ resource persons at political party meeting activities;

Other provisions that obligate PNS to act neutral are contained in Government Regulation Number 53 of 2010 concerning Civil Servant Discipline, article 3 point (4) that PNS is obligated to obey all provisions of laws and regulations. Furthermore, Article 4 Number (1) contains prohibitions for civil servants to abuse their authority. The provisions of these two articles reinforce the norms of the State Civil Apparatus Law for civil servants to act according to the outlined provisions. Deviation from the provisions of these articles, it can be categorized that the involvement of the state civil apparatus in politics (Pilkada) is a form of non-neutrality of ASN.

Meanwhile, the provisions, the prohibition for village heads and village officials are contained in Constitution of the Republic of Indonesia number 6 of 2014 concerning Villages Article 29 letter J, that the Village Head is prohibited from participating and/or being involved in general election campaigns and/or regional head elections. Furthermore, Article 51 letter J, states that village officials are prohibited from participating and/or being involved in the general election campaign and/or regional head elections. Furthermore, the prohibition for village assistants is contained in the Circular of the Director of Village Community Empowerment and the Directorate General of PPMD, Ministry of Disadvantaged Villages No. 727/DPMD.6/XI/2016 on 7 November Concerning Standard Operating Procedures for Guidance and Control of professional assistants, and contract agreements. Through this circular, village assistants are required to maintain professional behavior and ethics, including avoiding conflicts of interest, not being allowed to hold public positions/management of political parties, being neutral and impartial.

The various modes of involvement of the bureaucratic apparatus in the momentum of the Local Election in Konawe Selatan District vary greatly, include:

1. Post photos and comments on social media that lead to support or side with one of the candidate pairs;

2. The use of candidate pairs' campaign attributes, such as wearing clothes and installing stickers;

3. Attending campaign activities, face to face, socialization, visit residential areas (blusukan), and withdrawal of serial numbers of candidate pairs;

4. Following the declaration and convoy of candidate pairs.

5. Following religious meetings held by pairs of candidates;

6. Launching of the candidate pair program;

7. Meetings in political party offices attended by the State Civil Apparatus;

8. Advertising in the mass media;

9. Involvement as a volunteer team for candidate pairs and administrators of political parties;

10. Attending the inauguration of the candidate pair volunteer team and the establishment of the winning post;

11. Socializing candidate pairs.

Based on the distribution of areas, findings, and reports on the involvement of the bureaucracy in the simultaneous regional elections held in 2020 in Konawe Selatan District, this refers to the Bawaslu report, where the tendency of bureaucratic officials to provide support to incumbent candidates or incumbent families. Apart from supporting the incumbent, the bureaucratic apparatus also provides support to former superiors in the bureaucracy.

Theoretically, as many scientists have argued (Weber, 1966; Albrow, 1996; Halevi, 1983; Wright, 1992) bureaucracy is described as a modern organization that has a professional and neutral character from political interests. In fact, in the context of public administration, Frank J. Goodnow 
drew a clear line between bureaucracy and politics by saying that, although both are in the realm of government, politics and administration play different functions. Politics plays a function related to expressing the will of the state (expression the state will), while administration plays a function related to the problem of implementing state policies (the execution of these policies) (Goodnow, 1900, in Shafritz \& Hyde, 1997).

However, in reality, the bureaucracy cannot fully fulfill the ideal type as imagined by scientists to be neutral from politics. It is undeniable that bureaucracy was born as a result of the complexity of life in modern society. As a complex organization, bureaucracy is a reflection of the various interests that exist in society. Each of these interests competes for a comfortable position. Therefore political support is a necessity to occupy a position bureaucracy or in implementing a policy. As a result, the face of the bureaucracy cannot be separated from the existing political configuration.

It is as if it has become a general axiom that the bureaucracy in Indonesia cannot escape from political influence. The history of this nation has shown that bureaucracy has always been a tool for the political interests of the rulers power, to carry out development programs, but also to be actively involved in the political arena. At that time, the bureaucracy was more widely used as an instrument to maintain a single majority for the political power of the rulers (Golongan Karya). Through a concept called mono-loyalty, bureaucratic networks from the center to the regions were actively involved as pendulum votes in every general election that took place during the New Order regime. In the New Order era, the bureaucracy was not only not neutral, but also became an inseparable part of political interests.

A gleam of hope emerged when the 1998 reform in socio-political life in the country took place. The reform movement in the political field required the bureaucracy to be more professional and neutral in political affairs. Bureaucratic reform required the bureaucracy to be more creative, and innovative in responding to developments and dynamics of modern society. One of the most prominent changes in this era is the empowerment of the local bureaucracy in the regions, by providing sufficient space for regions to make decisions regarding programs in their regions.

However, these changes appear to be merely moving the locus of the problem of bureaucratic neutrality from the center to the regions. If in the past the bureaucracy was a tool of political interests of the central rulers, nowadays the bureaucracy is mostly used by local political authorities to gain and maintain power. The bureaucracy becomes increasingly prevalent during the implementation of regional head elections. Towards the implementation of the regional head elections, candidates for regional heads, especially incumbents, involve bureaucratic officials to get as many votes as possible.

Witnessing the conditions that have occurred in several regional elections, it is difficult to expect a bureaucracy that is sterile from political interests. Several factors cause bureaucratic neutrality in the implementation of the Pilkada, first, the status of the incumbent regional head candidate who remains active during the election. With a position that remains active during the elections, incumbent candidates are freer to move the bureaucratic apparatus in the interest of winning themselves. It is not difficult to distinguish between the role of a regional government and the position as a candidate for regional head. Therefore, the incumbent candidate should be inactive during the implementation of the election.

Secondly, the lure of promotion for the bureaucratic apparatus. This factor is one of the triggers for the involvement of the bureaucratic apparatus or ASN in supporting one of the candidates, especially the incumbent candidate. The hope of obtaining or a higher promotion makes the bureaucratic apparatus involved, both directly or indirectly in helping to win certain regional head candidates. Third, related to the second factor, the weakness of sanctions by the state civil apparatus commission. The sanctions given to non-neutral bureaucratic apparatus, especially from the state 
civil apparatus commission, do not cause a deterrent effect. In the case found in Konawe Selatan District, bureaucrats who were proven to be involved only received light sanctions, in the form of warnings to be careful and maintain professional ethics. Meanwhile, the heaviest sanctions found were in the form of a public apology statement. The sanction did not provide a deterrent effect on the contrary, it makes bureaucrats become e more and more immune. Even some ASN who have been involved in the Pilkada, get promotion after the election is over. On the other hand, the existence of the State civil apparatus commission appears to have a weakness in imposing sanctions on regional heads, who give promotions to ASN who have been involved in ethical violations.

Fourth, the weak supervision and enforcement of the election supervisory agency (Bawaslu and its staff). Various forms of violations, including the involvement of the bureaucratic apparatus in the elections, always occur in each election implementation. This of course reflects the lack of supervision of the competent institutions, namely Bawaslu and its staff. Bawaslu as a supervisory agency supposedly had anticipated violations like this so they would not be repeated. The oversight's negligence was easily exploited by the incumbent to mobilize the bureaucratic apparatus to win the election battle. In terms of prosecution, Bawaslu also seems difficult to rove and ensnares regional head candidates who use bureaucratic politicians. The obstacles experienced by Bawaslu come from internal and external.

Internally, Bawaslu has limited human resources both in quantity and quality (competence). In terms of quantity, Bawaslu staff resources are very limited and are faced with a large number of reports and findings. Meanwhile, the competence of election supervisory commissioners has not received maximum support from the secretariat, due to the uneven competence of secretariat staff in understanding the rules, and weak legal analysis. As a result, the handling of violations is still very simple, so sometimes it cannot convince the police, and the prosecutor's office for cases of criminal election that are handled. From externally, Bawaslu is not supported by laws and regulations that can impose severe sanctions on candidates for regional heads who use bureaucracy as a political tool.

Fifth, the fifth factor is related to the fourth factor, namely the weak sanctions for regional head candidates that involve the bureaucracy. Bureaucratic involvement that keeps repeating itself due to the light sanctions imposed on regional head candidates. As stipulated in the Local Election Constitution Number 10 of 2016, article 189 that a regional head candidate who involves the bureaucracy, is subject to a minimum of one-month imprisonment, and a maximum of 6 months, and a minimum fine of six hundred thousand rupiah, and at the most six million rupiah high. The criminal sanctions should be even more severe and be accompanied by administrative sanctions that can have a deterrent effect, such as cancellation of nominations, support for the inauguration, and dismissal of regional heads who are proven to move the bureaucracy.

If the above factors have not been resolved, it is difficult to expect a neutral bureaucracy in the regional elections. This condition will have further effects, both for the professionalism of the bureaucracy and the quality of democracy. The involvement of the bureaucracy in politics in general and the elections in particular will make the bureaucratic performance unprofessional, so that public services will be disrupted. In terms of the quality of democracy, the involvement of the bureaucracy in the elections will create unfair competition, which injures the integrity of the implementation of the elections. Thus it is difficult to produce democratic elections. All this will lead to the emergence of elected regional heads who are not qualified.

\section{CONCLUSION}

The involvement of the bureaucracy in Local Election in Konawe Selatan District is generally found in the State civil apparatus (ASN) and village government officials (Village Heads, Village 
Officials, and Village Assistants). The various modes of involvement include: a. Post photos and comments on social media; b). Use of campaign attributes; c). Attending campaign activities, face to face, socialization, and blusukan of candidate pairs; d). Following the declaration and convoy of candidate pairs; e). Program launching; f). Meetings in political party offices; g). Advertising in the mass media; h). Involvement as a volunteer team; i) Attendance at the volunteer team inauguration; $j$ ). Socializing; k) Attending the serial number revocation activity.

It appears that the involvement of the bureaucracy in the Pilkada has a very close relationship with the incumbent candidate. Meanwhile, the factors that encourage bureaucratic involvement in Local Election in Konawe Selatan District are: first, the status of incumbent regional head candidates who remain active during the implementation of the elections; second, the lure of promotion for the bureaucratic apparatus; third, weak sanctions from the state civil apparatus commission; fourth, weak supervision and enforcement of election supervisory institutions (Bawaslu and its staff); fifth, weak sanctions for regional head candidates. Therefore this study provides recommendations, including deactivation of incumbent regional head candidates, sanctions for ASN involved in Pilkada and regional head candidates involving the bureaucracy, and strengthening the quality of Bawaslu resources.

\section{REFERENCES}

1. Agustino, Leo. (2014). Patronase Politik Era Reformasi: Analisa Pilkada di Kabupaten Takalar dan Provinsi Jambi. Jurnal Administrasi Publik, 11 (2).

2. Albrow, Martin. (1996). Birokrasi. Yogyakarta: Tiara Wacana.

3. Bawaslu Kabupaten Konawe Selatan. (2018). Laporan Akhir Penangangan Pelanggaran Pemilihan Gubernur dan Wakil Gubernur, Bupati dan Wakil Bupati, Serta Walikota dan Wakil Walikota Tahun 2018.
4. Creswell, J. W. (2014). Research Design: Qualitative, Quantitative, and Mixed Methods Approaches (4th ed.). London: SAGE.

5. Halevy, Eva Etzioni. (1983). Bureaucracy and Democracy A Political Dilemma. London: Routledge Kegan Paul.

6. Hamid, Abdul. (2011). Politisasi Birokrasi dalam Pilkada Banten 2006. Jurnal Ilmu Administrasi Negara, 11 (2), 97 -110.

7. Heilbroner, Robert L. (1982). Terbentuknya Masyarakat Ekonomi. Jakarta: Ghalia Indonesia.

8. Hill, Larry B. (ed). (1992). The State of PublicBureaucrac. New York: M. E. Sharpe Inc.

9. Miles, Matthew B. and A. Michael Huberman. (2005). Analisis Data Kualitatif. Jakarta: UI Press.

10. Rozi, Syafuan. (2006). Zaman Bergerak, Birokrasi Dirombak: Potret Birokrasi dan Politik Indonesia. Jakarta: LIPI \& Pustaka Pelajar.

11. Shafritz, Jay M and Albert Hyde C. (1997). Classic of Public Administration. Forth Worth, Harcourt Brace Colkeges Publisher.

12. Sihotang, Lia Eldest. (2013). Birokrasi dalam Pemilihan Kepala Daerah (Studi Kasus: Ketidaknetralan Birokrasi dalam Pemilihan Kepala Daerah Kota Pekanbaru Tahun 2011). Tesis: Universitas Gadjah Mada.

13. Suryadinata, Leo. (1992). Golkar dan Militer: Studi tentang Budaya Politik. Jakarta: LP3ES.

14. Thoha, Miftah. (2009). Birokrasi Pemerintah Indonesia di Era Reformasi. Jakarta: Kencana.

15. Weber, M. (1946). From Max Weber: Essay in Sociology. New York: Oxford University Press.

16. Wright, Vincent (Ed). (1992). Comparative Government and Politics an Introduction. London: The Macmillan Pres Ltd. 